The Four Horsemen of the Apocalypse: Understanding

Human Security

Faculty Research Working Paper Series

\title{
Ronald F. Inglehart
}

University of Michigan

Higher School of Economics, Moscow and St. Petersburg

\section{Pippa Norris}

Harvard Kennedy School

University of Sydney

\section{October 2011 \\ RWP11-039}

The views expressed in the HKS Faculty Research Working Paper Series are those of the author(s) and do not necessarily reflect those of the John F. Kennedy School of Government or of Harvard University. Faculty Research Working Papers have not undergone formal review and approval. Such papers are included in this series to elicit feedback and to encourage debate on important public policy challenges. Copyright belongs to the author(s). Papers may be downloaded for personal use only. 


\title{
The Four Horsemen of the Apocalypse:
}

\section{Understanding Human Security}

Ronald F. Inglehart

\begin{tabular}{|c|c|c|c|}
\hline \multirow[b]{2}{*}{$\begin{array}{l}\text { Institute for Social } \\
\text { Research }\end{array}$} & \multirow{2}{*}{\multicolumn{2}{|c|}{\begin{tabular}{c|c} 
Laboratory for & John F. Kennedy School \\
of Government
\end{tabular}}} & \multirow{3}{*}{$\begin{array}{c}\text { Department of } \\
\text { Government and } \\
\text { International Relations } \\
\text { University of Sydney }\end{array}$} \\
\hline & & & \\
\hline University of Michigan & $\begin{array}{l}\text { Research } \\
\text { Higher School of } \\
\text { Economics }\end{array}$ & Harvard University & \\
\hline $\begin{array}{c}\text { Ann Arbor, Michigan } \\
48106\end{array}$ & $\begin{array}{l}\text { Moscow and St. } \\
\text { Petersburg }\end{array}$ & Cambridge, MA 02138 & Sydney, NSW, 2600 \\
\hline \multicolumn{2}{|c|}{$\begin{array}{l}\text { ringlehart@gmail.com } \\
\text { www.worldvaluessurvey.org }\end{array}$} & \multicolumn{2}{|c|}{$\frac{\text { Pippa_Norris@,Harvard.edu }}{\text { Pippanorris.com }}$} \\
\hline
\end{tabular}

\begin{abstract}
Since the end of the Cold War, security studies have broadened to take into account a wide range of non-military threats ranging from poverty to environmental concerns rather than just national defense. Security scholars, backed by international organizations and a growing number of national governments, have developed the concept of Human Security, focusing on the welfare of ordinary people against a broad range of threats. This has aroused vigorous debate. Part I of this paper proposes an analytical model of Human Security. Part II argues that it is important to measure how ordinary people perceive risks, moving beyond state-centric notions of Human Security. We examine new evidence, drawing upon survey items specially designed to monitor perceptions of Human Security, included for the first time in the $6^{\text {th }}$ wave of the World Values Survey (WVS), with fieldwork conducted in 2010-2012.Part III demonstrates that people distinguish three dimensions: national, community, and personal security and then explores some structural determinants driving these perceptions. Part IV discusses why perceptions of Human Security matter, in particular for explaining cultural values and value change around the world. The conclusion argues that the shift from a narrow focus on military security toward the broader concept of Human Security is a natural response to the changing challenges facing developed societies, in which the cost-benefit ratio concerning war has become negative and cultural changes have made war less acceptable. In this setting, valid measures of perceptions of Human Security have become essential, both to understand the determinants of Human Security among ordinary people, and to analyze their consequences.
\end{abstract}

Revised paper for Scandinavian Political Studies. 10,622 words 
Since the end of the Cold War, security studies have broadened to take into account a wide range of non-military threats, such as environmental problems, disease epidemics, poverty, nationalism, terrorism, failing states, and vulnerable information systems. Security scholars, backed by international organizations and a growing number of national governments, have developed the concept of Human Security, focusing on the welfare of ordinary people facing a broad range of threats, including national defense but extending well beyond it.

Not surprisingly, the attempt to revise traditional understandings of security has aroused vigorous debate. ${ }^{1}$ Proponents contend that this reconceptualization dissolves conventional disciplinary boundaries and existing paradigms, so that the links between multiple risks and threats are better understood in an increasingly complex and globalized world.2In response, traditionalists argue that Human Security is a muddled, value-laden, and confusing catch-all notion, where a mélange of diverse challenges are 'securitized', without providing any additional analytical leverage for scholars or practical utility for policy analysts. ${ }^{3}$ The conventional conception of security, traditionalists suggest, emphasizing the role of the state indefending national interests against external threats, provides a sharper focus. Scholarly debate about these issues has been mainly theoretical and normative. Researchers have started to explore the empirical evidence, however; hence discourse analysis has been utilized to determine whether the concept of Human Security has penetrated the diplomatic language framing foreign policy speeches and official documents. ${ }^{4}$ Several casestudies have examined whether the actions of leading advocates reflect the principles of Human Security, such as the foreign policies of Canada and Japan. ${ }^{5}$ Studies have attempted to construct Human Security Indexes, based on national-level data. ${ }^{6}$ By contrast, little empirical work has sought to measure subjective perceptions of Human Security among ordinary people, to compare these perceptions among and within diverse societies worldwide, to identify the core drivers of this phenomenon, still less to analyze the consequences for cultural change.

To address these issues, this study starts by considering alternative understandings of the concept of Human Security. Part I proposes a model of Human Security, generating propositions that are theoretically important and empirically testable. Our theory predicts that experience of 'objective' structural conditions, at national, community and personal levels, will affect perceptions of Human Security. Thus feelings of vulnerability to risk and threat will be stronger among those experiencing major wars or natural disasters, growing up in risky neighborhoods, and among the more susceptible sectors of the population, such as the elderly, the poor, women, and those with fewer skills and education. Security perceptions are also expected to be conditioned by the social safety nets provided by the family, community, and welfare state, which can mitigate risks, as well as by the depiction of threats and dangers conveyed in mass communications (the 'mean world 'effect). In turn, security perceptions are predicted to shape a wide range of cultural values, including feelings of well-being and happiness, social trust and tolerance, the strength of religiosity, and 
political orientations, such as support for right-wing parties, attitudes towards gender equality, and sexual liberalization values.

Part II in this study discusses a new measure which operationalizes perceptions of Human Security. In the previous literature, Human Security has been measured at the level of nation-states. The most ambitious attempts to create a composite Human Security Index have sought to compare national-level inequalities worldwide based on internationally-standardized official statistics. Measures have constructed threshold estimates (to gauge the severity of threats) using indices in each society, such as poverty (GDP per capita), food (the proportion under-nourished), health (child mortality rates), environment (access to water), personal security (the political terror scale) and political security (press freedom). ${ }^{7}$ This approach is useful but it is also limited, since mean and median scores can disguise substantial disparities within societies, and the existence of marked inequalities in security among vulnerable populations. There are no clear principles to select and weight the components parts nor the appropriate threshold. The measures are therefore constructed on an ad hoc basis, selecting variables arbitrarily, often based on data availability, without monitoring to what extent they actually impact on a given people's sense of risks and threats. It also remains unclear what value the composite measures add for public policymakers. Saying that a country such as Somalia or Haiti ranks low in overall Human Security (which seems intuitively obvious) tells us nothing about whether donor aid should be spent strategically on, say, training the police force, funding water wells, or supporting clinics. The macro-level composite measures are also conceptually flawed, since they perpetuate a state-centric perspective. To develop more specific and policy-relevant insights, measures of Human Security ideally need to be analyzed at the individual-level. The measure used in this study therefore compares how ordinary people perceive risks. This strategy allows the analysts to then re-aggregate the data, for example to monitor how far perceptions of Human Security vary among women and men, rich and poor households, those living in the rural periphery and those in the urban center, different ethno-religious or ethno-linguistic communities, and to measure the drivers of peoples' sense of security. This measure also facilitates comparisons of what shapes a sense of security across countries, types of societies or regimes, and global regions. Evidence is drawn from a new battery of survey items designed to monitor perceptions of Human Security, included for the first time in the $6^{\text {th }}$ wave of the World Values Survey (with fieldwork conducted in 2010-2012). Data for this wave continues to be collected, but we examine some preliminary results. The available evidence allows us to compare several diverse nations, including rich societies and long-established democracies, such as Sweden and the United States, as well as several middle-income and poorer developing societies from different global regions. Dimensions of perceived Human Security are measured and compared across and within societies.

Part III explores the structure and dimensions of perceptions of Human Security, using factor analysis. The results suggest that the public distinguishes between three components or dimensions: national 
security (the broadest level, in terms of threats from armed conflict), community security (including threats from the surrounding neighborhood), and personal security (involving risks and threats to the self and family). Thus the object of the security risks appears to be as important to most people as the cause of the threat. The results suggest, as traditionalists emphasize, that concern about the risks to the nation-state arising from internal violence, inter-state war and terrorism remains an important and distinct dimension of public perceptions of Human Security, focused on 'freedom from fear'. Nevertheless the findings also lend some support to the revisionist perspective, by emphasizing that perceptions of Human Security also encompass and recognize other important types of threat and risk, such as those arising from crime and illicit drugs, and personal insecurity from lack of food or income, emphasizing 'freedom from want'. Further analysis suggests that each dimension of perceived Human Security can be explained most plausibly by a distinctive range of structural conditions. For example, as might be expected, the analysis shows that reported levels of household income and wealth have far strong effects on feelings of personal insecurity(such as going without food or medical treatment), than on feelings of national insecurity(such as the risks of war and armed conflict).

Part IV discusses why perceptions of Human Security matter, impacting feelings of human wellbeing and happiness, social tolerance, and cultural values around the world. The conclusion argues that more robust and conceptually valid measures of perceptions of Human Security are essential, both to understand this phenomenon at the individual-level, and also to analyze its consequences. In a series of previous publications, we have theorized that perceptions of Human Security have major cultural implications, including for trends in religiosity and secularization, for attitudes towards gender equality, and for general processes of value change. ${ }^{8}$ The new evidence allows these predictions to be tested more systematically and more rigorously than ever before. Understanding perceptions of Human Security is emerging as a promising research agenda with the capacity to transform the predominant paradigm in security studies, shifting the focus from military violence to other severe threats, and from states to peoples.

\section{I: The concept of Human Security}

The United Nations has often pioneered concepts which have been widely disseminated, such as 'human development', 'sustainable environments' and 'good governance'. The intellectual roots of the UN's work in promoting general ideas of human security can be traced back to the 1940s. ${ }^{9}$ Dr. Mahbub ul Haq first drew the widespread attention to the concept of Human Security in the seminal United Nations Development Programme's 1994 Human Development Report. "The concept of security "has for too long been interpreted narrowly: as security of territory from external aggression, or as protection of national interests in foreign policy or as global security from the threat of nuclear holocaust....Forgotten were the legitimate concerns of ordinary people who sought security in their daily lives." 10 This report proposed seven major components of Human Security: (1) economic security; (2) food security; (3) health security; (4) environmental security; (5) personal security (safety from such things as torture, war, criminal attacks, domestic violence, drug use, suicide, and traffic accidents; (6) community 
security (the survival of traditional cultures and ethnic groups); and (7) political security (the enjoyment of civil and political rights, and freedom from political oppression). ${ }^{11}$ Human security was also envisaged in the report as universal (applying to all people and societies), interdependent (where diverse types of threats are linked together), preventative (where the primary concern is to ameliorate and reduce the causes of insecurity), and people-centered (focusing upon individuals not just relationships among nation-states). The report also introduced the important notion of subjective security -- what makes people feel safe -- referring to 'Human Security as people see it, in contrast to objective indicators of income inequality or armed violence.

The core idea therefore expands the concept of security beyond narrow conceptions of state defense against external military threats. Human Security recognizes the complex links between 'freedom from fear' and 'freedom from want', anticipated decades earlier in Franklin D. Roosevelt's speech (1941).12 In this regard, the revisionist conception promises to reintegrate separate scholarly disciplines focused upon military security and international development.

Moreover, and equally importantly, the concept also refers to the comprehensive protection of peoples, not just the security of states. This shifts beyond the state-centric analysis that has dominated international relations during the post-Westphalian era to focus upon a wide range of actors, including individuals, social groups, and local communities. It recognizes that states may function as the primary protection for their citizens - but that repressive states may also be their abusers. It also breaks down the dichotomous classifications of developed and developing nations, recognizing that prosperous and secure citizens living in Cape Town may have more in common with similar citizens in Sydney, Santiago, and Stockholm, than with their countrymen in Johannesburg, Durban and Pretoria. Beyond this minimal agreement, however, there is no shared consensus about the precise boundaries of this notion.

The 1994 Human Development Report influenced the language and principles of external relations and international affairs among the governments of several major powers. Canada, Norway and Japan led the way by incorporating notions of Human Security into their foreign policies, although with differing conceptualizations. ${ }^{13}$ In 1998, governments, led by Canada and Norway, established a "Human Security network" of states and nongovernmental organizations that endorse the concept. ${ }^{14} J a p a n$ also promoted this framework, emphasizing threats from economic crisis, social safety nets, global warming, transnational crime, refugees, human rights violations, landmines and child soldiers. ${ }^{15}$ Japan actively furthered the idea within the international community by funding several initiatives, including the UN Commission on Human Security. ${ }^{16}$ In 2000 and 2004 the Swedish parliament passed resolutions that have transformed the role of the Swedish Armed Forces. Previously, the Swedish military had been mainly oriented toward repelling an invasion of Swedish territory, but the risk of invasion is now seen as low. The new policy holds that: "Defending a nation has historically been equivalent to protecting its borders. Today, defending a nation can take place far away, through creating peace, stability and prosperity in turbulent parts of the world. In this manner, defending a nation has come to include defending its 
values, and protecting democracy or buman rights." Accordingly, Swedish Armed Forces personnel are now mainly involved in international peace support and humanitarian operations, carried out in such places as Afghanistan, Kosovo, Bosnia, Liberia, DRC and Lebanon. Similarly, in 2008 the Australian government announced that its new defense policy would incorporate Human Security concerns such as the environment, terrorism and crime, energy security, infectious diseases and global demographic changes, as well as national security. ${ }^{17}$ Another major change in international politics-- the rising emphasis on the concept of Human Rights that has emerged in recent decades-- is closely related to the growing emphasis on Human Security. The European Union has not formally adopted the Human Security framework for its external relations but Mary Kaldor argues that many of its policy priorities and principles, including concepts of crisis management, civil-military cooperation, and conflict management, have been framed in the language of Human Security. ${ }^{18}$ Several critics charge that the adoption of the Human Security framework is 'the dog that did not bark', mainly affecting the language and discourse used to frame and justify external relations by several governments, without profoundly altering practices. ${ }^{19}$ Others scholars suggest that the new thinking has now gone beyond rhetoric to guide external relations among leading proponents, such as Canada and Japan, as well as generating several new human security-driven examples of state and non-state actor collaboration, exemplified in the Ottawa Convention on landmines, the Kimberley Process on conflict diamonds, and the establishment of the International Criminal Court. ${ }^{20}$

The idea of Human Security continues to stir debate among scholars in international relations and development studies. One reason for the popularity of this concept lies in the attempt to understand the changing functions of security forces in recent decades, in which the international community has expanded peace-keeping operations following both intra-state and civil wars. ${ }^{21}$ Interventions have broadened in scope well beyond the provision of blue-helmet security to cover challenges of overcoming human suffering, economic destruction, social reconstruction, and securing agreement for new constitutional settlements. The expansion has been fuelled by widespread concern that societies deeply-divided by conflict and violence, where long-standing autocracies have collapsed, are breeding grounds for terrorism, organized crime, weapons proliferation, humanitarian emergencies, environmental degradation, genocide, and political extremism. ${ }^{22}$ Experience with peace-keeping operations in trouble-spots such as Somalia, Timor Leste, Sierra Leone, and the Democratic Republic of the Congo, has spurred renewed efforts to understand the challenges of military security and social reconstruction. The core role of international peace-keeping forces to reduce inter-communal violence, clear land-mines, and collect small arms, and has expanded so that today the military have become inextricably concerned with such challenges as distributing food and medical aid, supervising reconstruction efforts, facilitating processes of negotiated settlement and constitution-building, and expanding the capacity of local security services. Reflecting these developments, proponents argue that the concept of Human Security has the potential to be paradigm-shifting within international relations, 
dissolving traditional disciplinary barriers which have divided scholars studying territorial defense from others focused upon issues of international development, economic growth, social protection, regime transitions and processes of democratization. ${ }^{23}$ The interdisciplinary study of Human Security brings together experts on issues of human rights, crisis management and vulnerable populations, conflict resolution, and international development as well as military security.

This shift in elite thinking reflects changing value priorities found among the publics of advanced industrial societies. When states first emerged, their primary function was to maintain a monopoly of violence, defending their people against internal violence and conquest by outsiders. This was crucial to survival because food was scarce. Throughout most of history, population rose to meet the available food supply, and most people lived at the subsistence level. Violence was necessary to protect the scarce means of sustenance. The elite that maintained a monopoly of violence tended to appropriate any surplus for themselves leaving the masses at the subsistence level, but with the advantages of being exploited by stationary bandits rather than roving ones. Under these conditions, security studies largely boiled down to the study of military security.

This has been changing, starting with the economic miracles of the post-war era, and accelerating with the end of the Cold War. A concept of Human Security has emerged, still embracing military security but now including a much broader range of concerns. Among developed nations, inter-state war has become less widespread for two reasons: it has become (1) less cost-effective and (2) less acceptable to the publics of developed democracies. At the same time, globalization and cultural change have made other concerns such as environmental protection and human rights increasingly prominent. These developments reflect economic, technological and social changes linked with modernization. A massive body of survey evidence demonstrates that in countries that have experienced rising levels of economic and physical security, mass value priorities have been shifting from a relatively narrow focus on survival, toward a broader range of goals. In response, governments in several developed countries have been expanding their security policy priorities from military defense to the broader concept of Human Security. Given the persistence of enduring poverty, disease, and conflict around the world -- key drivers of fear and want -- it is critical to monitor threats to Human Security and to diagnose the most important determinants of success and failure in reducing risks.

[Figure 1]

The heuristic model presented in Figure 1 can be used to understand perceptions of Human Security. The core components are only sketched in here although the logic can be briefly described. Our theory predicts that perceptions of Human Security will reflect experience with 'objective' structural conditions, at global and national (macro), community (meso) and personal (micro) levels. Thus perceptions of insecurity will be stronger among those living through major wars or natural disasters, growing up in risky 
neighborhoods, and among the more vulnerable sectors of the population, such as the elderly, the poor, women, and less educated. The exact weight and influence of each of these factors remains to be determined, however, for example whether socio-tropic or ego-tropic evaluations of risks have the strongest impact on security perceptions. Drawing upon the public health literature, a large body of research has studied the relationship between objective indices of risks and subjective assessments of threats. Security perceptions seem to be conditioned by the social safety nets provided by the family, community and the welfare state, which can mitigate risks. Informal networks function as the first form of support, mitigating care of the elderly or children, and coping with natural disasters. Philanthropic and religious organizations, trade unions, and other cooperative associations and local networks can also provide help in time of need. Security perceptions are also expected to be affected by the depiction of threats and dangers conveyed in mass communications (the 'mean world 'effect).

In turn, as discussed in the final part of this paper, security perceptions are predicted to shape a wide range of cultural values, including feelings of well-being and happiness, social trust and tolerance, the strength of religiosity, and political orientations, such as support for right-wing parties, attitudes towards gender equality, and sexual liberalization values. In this preliminary study, we cannot set out the full evidence demonstrating the connections among all the components in our theory, which is part of a larger research project. But we will develop and operationalize the core measure of perceptions of security and illustrate some of the relationships with preliminary WVS data.

The concept of Human Security still remains highly controversial, and questions have been raised about the concept's theoretical coherence. Many traditionalists contest the theoretical coherence of the idea, arguing that the notion is conceptually vague and normatively-driven, reflecting a 'shopping list' of diverse popular concerns, that should be kept analytically separate. Dispute remains about whether to adopt narrow or extended definitions, with traditionalists charging that, the broadness of the potential range of threats which could be included under this idea reduces the utility and precision of the concept. ${ }^{24}$ If everything becomes a matter of 'security' - from food security to environmental security, political security, and economic security, then traditionalists believe that the word loses its core meaning and simply becomes a rhetorical rallying cry. Where issues such as famine, HIV-AIDS and climate change become 'securitized', this process increases their claims to priority and attention on the policy agenda and budget.

Even if acknowledged as theoretically important, the idea is also still regarded as difficult to measure with the rigor and precision necessary for empirical research, for monitoring risks, and for guiding strategic policy priorities. Critics suggest that the abstract concept of Human Security is so conceptually ambiguous, normatively-laden, and all-encompassing that it is difficult to measure with any validity, reducing its practical utility for scholars and policymakers. ${ }^{25}$ Insufficient efforts have been made to operationalize the term. ${ }^{26}$ As a 
result, the notion has not yet been employed in a coherent and precise way that could help guide policy priorities within the international development community.

\section{II: Measuring Human Security}

The measurement challenge is real - but, we argue, not insurmountable. King and Murray argue that Human Security is potentially open to operationalization, within the limits of the available data, by focusing upon the most severe threshold of a range of life-threatening risks. ${ }^{27}$ They offer a definition of Human Security that is intended to include only essential elements that are "important enough for human beings to fight over or to put their lives or property at great risk." 28 King and Murray identify five key indicators of Human Security — poverty, health, education, political freedom, and democracy. Paris, however, argues that this list selects certain values as representing Human Security, without offering a clear justification for doing so. ${ }^{29}$ Why is political freedom included but not, say, the threat of environmental degradation or the risks of disease epidemics, floods, famine? If measured by the degree of fatalities, arguably disasters have more severe effects than lack of political freedoms.

Other similar attempts to construct an index based on the concept of Human Security have combined a range of standard indicators available at national-level, exemplified by levels of battle-related deaths, average longevity, rates of infant mortality, and estimates of poverty. ${ }^{30}$ But again, it remains unclear which macro-level indicators should be included or excluded, how these should be combined and weighted, and what level or threshold constitutes a 'severe' threat. ${ }^{31} \mathrm{~A}$ widespread consensus surrounds many internationally-standardized measures of human development, such as those used to monitor progress towards meeting the Millennium Development Goals, for example concerning levels of child mortality, rates of tuberculosis or measles, and levels of per capita GDP. ${ }^{32}$ Similarly the scholarly literature has developed standard measures of the severity of intra-state and internal armed conflict, monitored by battle-related deaths and casualties, such as those collected by the Uppsala Conflict Data Program (UCDP) for the PRIO Armed Conflict Dataset 1946-2009.33 But there is a serious aggregation problem in any broader measure: it remains unclear how to combine separate macro-level indicators into a rigorous, coherent and valid composite measure reflecting the underlying concept of Human Security. Composite indices also lose much of the fine grained detail which is essential for accurate policy diagnosis and prescription; if a particular country is low in Human Security, is this due to natural disasters, military aggression or endemic poverty? We would not know from the overall rating.

\section{National or Individual-level measurement}

Another reason why previous attempts to measure Human Security remain flawed, we suggest, is a unit of analysis problem. Previous measures remain state-centric by using macro-level indices focused on the nation-state. By contrast, few have attempted to compare public perceptions and experience of the different 
components underlying the concept of Human Security. ${ }^{34}$ Yet it is particularly important to understand what makes people feel safe, measured by subjective perceptions at individual-level, for several reasons.

Firstly, as mentioned earlier, the original notion of Human Security emphasized that a distinctive aspect of the concept was that it was 'people-centric' rather than state-centric. Common patterns of social inequality mean that even in affluent post-industrial economies, many sectors of society still feel excluded from welfare safety nets, marginalized from public affairs, and vulnerable to poverty, violent crime, and social deprivation. Individual-level measurement is essential since people and groups can still feel vulnerable to existential threats even in rich and stable societies. The powerful notion of Human Security therefore cuts across thinking based on simple global comparisons between states: Human Security is a particularly serious challenge for the most vulnerable populations living in less developed societies and weak states, but it can also be a threat for all mankind. Thus we need to examine perceptions of Human Security by focusing upon the most vulnerable populations, such as the young and elderly, the poor and unemployed, women, and refugees, migrants, minority groups, as well as comparing how Human Security varies geographically within countries by sub-region and among those living in the rural periphery and major cities. Expanding social inequality in many societies, even those such as China and India with rapid national economic growth, makes this issue particularly important.

Moreover a substantial literature in social psychology, communications and public health suggests that there can be major discrepancies between 'objective' and 'subjective' perceptions of risk and threat. Thus, for example, the 'mean world effect' literature, based on cultivation theories of American public opinion, suggests that official rates of violent crime monitored in policy statistics can fall, making communities safer places to live, although the public believes that the risks of crime have risen, due to exposure to extensive coverage of violent crime on local TV news coverage or watching crime drama programs highlighting this issue. ${ }^{35}$ Similarly our ability to identify the health risks arising from diet, smoking, or lack of exercise with any degree of accuracy are widely recognized to be flawed, whether due to perceptual biases, limited cognitive skills, or lack of adequate information. We therefore need to be able to compare perceptual and 'objective' indices of security, to understand this complex relationship. By approaching the operationalization of Human Security and monitoring individual-level perceptions, it also can be established whether ordinary people living in different types of society regard severe threats to their lives as essentially one-dimensional, or whether people distinguish among different types of risks.

\section{Evidence, comparative framework and survey data}

Evidence presented in this study draws upon a new battery of survey items designed to monitor perceptions of Human Security, included for the first time in the $6^{\text {th }}$ wave of the World Values Survey (WVS), with fieldwork conducted in 2010-2012. At present, data for the $6^{\text {th }}$ Wave of the World Values Survey 
continues to be collected, but the currently available data allows comparisons to be drawn among and within several diverse societies. This include some nations ranked as highest in the world by the UNDP 2010 Human Development Index, with stable democracies as well as high levels of national security, including the United States, Sweden, Japan, the Republic of Korea, and Spain. The latter two societies have also registered remarkable progress in human development and democratization during the third wave era. The comparison also includes several diverse countries from different global regions enjoying moderate to low levels of human development- including Trinidad and Tobago, and Morocco. The countries included in the comparative framework also allow comparison among societies which have developed diverse types of welfare states and social safety-nets, such as contrasts between Sweden and the United States. Comparisons can be drawn among regimes governed by traditional monarchies (Morocco), presidential executives (including the United States) and parliamentary democracies (such as Spain), with dissimilar historical experience of regime transitions and processes of democratization. Societies also vary in their recent experience with armed conflict, both at home and abroad; hence Spain has contended with violence in the Basque region, and the Republic of Korea faces severe military threats across the border from the North. Countries such as the United States and Sweden also differ sharply in their foreign policies, military capacity, and willingness to deploy armed force abroad. The exploratory generalizations based on the preliminary analysis of these countries will be tested in an even broader range of nations following release of the full set of WVS data from 2010-2012.

\section{Part III: Public perceptions of Human Security}

The $6^{\text {th }}$ Wave of the WVS survey included a series of items designed to monitor public perceptions of a range of risks and threats. The items are shown in details in the paper's Technical Appendix. Principal components factor analysis was employed to determine whether public perceptions were uni-dimensional or whether people distinguished between different types of threats. Public perceptions across all countries included in the pooled WVS were found to fall into three dimensions, reflecting notions of personal security, community security and national security. Table 1 shows the results of the factor analysis. As it indicates, one dimension concerns the frequency of threats to the local community, such as robberies, illicit drugs and alcohol consumed in the streets in the immediate neighborhood. Another dimension concerns national security, including concern about terrorist attacks, inter-state war and civil war. A third dimension involves personal security, including the experience of going without cash income, medicine, enough food to eat and feeling unsafe about crime in the home.

[Table 1 about here]

Accordingly three normalized scales were developed by adding each of the items, standardized to a 100-point scale for ease of comparison across each dimension. Each of the scales was reversed for analysis so 
as to focus upon determining some structural causes of insecurity and perceptions of risk. The results in Table 2 illustrate the main contrasts in mean scores in insecurity perceptions on the 100-point scales by society.

[Table 2 about here]

As might be expected, in terms of personal threats, Sweden emerged as the most secure nation, followed by the other post-industrial nations, with Morocco, the society with the lowest per capita income, proving the least secure. On average, perceptions of personal insecurity were almost twice as strong in Morocco as in Sweden. In terms of perceptions of community security, however, while the Japanese displayed the strongest feelings of neighborhood safety, the other post-industrial societies proved remarkably similar. Perceptions of community insecurity were strongest in the two developing societies, Morocco and Trinidad and Tobago.

Lastly comparisons of national insecurity reversed some of these patterns among the countries under comparison. Thus fears about the threat of terrorism, civil conflict and inter-state war were greatest in Japan, perhaps due to the long-standing historical memories from World War II, in keeping with other indicators of Japanese unwillingness to engage in aggressive military actions. Citizens were also concerned about national security in the Republic of Korea, not surprisingly given its chronic tensions with North Korea. Since the end of the Korean War, the two countries have faced each other across the Demilitarized Zone, engaged most of the time in hostile relations with occasional, brief thaws and increasing exchanges between P'yongyang and Seoul. Moroccans were also worried about war, in the context of the Arab Spring, sparked by events in Tunisia in December 2010 and the start of the Egyptian protests in January 2011, five months before the Moroccan survey. Moreover Western Sahara was long the site of armed conflict between Moroccan forces and the POLISARIO Front, which continues to seek independence for the territory. A cease-fire has been fully in effect since 1991 in the UN-administered area. By contrast, the risks were perceived to be lowest in Sweden, reflecting its long-standing tradition of pacifism, non-alignment, and neutrality. Sweden therefore emerges as the country with the least concern about both national and personal forms of security. Interestingly, it has made striking revisions in its defense policy, shifting from a focus on national defense to emphasizing peace-keeping and developmental aid as the central mission of the Swedish military.

How far do structural factors help to explain perception of security? The heuristic model used in this study predicts that feelings of personal insecurity will be strengthened by experience with a range of socioeconomic risks, including lack of income and wealth, educational qualifications and employment, and the working class, as well as being stronger among the elderly, women, the unmarried, and ethnic minorities. These factors are also expected to influence perceptions of community and national insecurity, although with 
progressively weaker effects. Table 3 shows the results of the OLS regression models where these factors were entered.

[Table 3 about here]

The results in the first model confirmed the impact of socioeconomic conditions on perceptions of personal security. Not surprisingly, the least secure sectors of society had low levels of household income, wealth (savings), educational qualifications, and subjective working class status. These were all strong and significant predictors of personal insecurity. The elderly, second generation immigrants, and those living in households where the chief wage earner was unemployed were also less secure, although both sex and marital status proved insignificant.

[Figure 2 about here]

To examine this in more detail, Figure 2 describes perceptions of personal security by income decile for each of the countries under comparison. The distribution shows that in general the more affluent households feel more secure, but the gap between rich and poor is moderate in Sweden, whereas there are sharp contrasts in Morocco - and in the United States. Indeed, out of all the countries under comparison, perceptions of personal risks are second highest among the poorest sectors of society in America. Wellestablished contrasts between the generous and comprehensive 'cradle-to-grave' social protection policies in the Swedish welfare state compared with more limited provisions in the United States, especially lack of universal health care, are likely to contribute towards the contrasts in personal security observed among the low-income households in these countries.

The final two regression models in Table 3 examine how far social structural and demographic variables also explain feelings of community and national insecurity. If these feelings reflected psychological traits, so that anxious personalities were fearful of many types of risks and threats, then similar social characteristics should predict each type of insecurity. It is apparent that the effects of education and wealth serve to reduce insecurities across the board. These factors are often closely intertwined, since higher educational qualifications serve as a springboard for higher-salaried professional and managerial careers. Most of the other predictors of national insecurity and fear of war, however, differ from the factors driving personal or community insecurities. Thus for example women are far more concerned about the risks of war than men, a well-known observation from previous studies of public opinion. ${ }^{36}$ By contrast, perhaps surprisingly, there are no apparent gender gaps in perceptions of personal and community security. For example, ethnic minorities (defined as second generation immigrants) have higher levels of personal and community insecurity, not surprisingly given the concentration of many minorities in urban areas with social deprivation, as well as low-income jobs. Yet minorities are significantly less concerned about the risks of terrorism, civil conflict, or inter-state war. Thus we can conclude that many of the structural factors 
contributing to social inequality help to explain perceptions of security - but the effects are far stronger for feelings of personal security than for perceptions of national security.

\section{IV: The Consequences of Human Security for Cultural Change}

Why does Human Security matter?

During the past 40 years, the world as a whole has experienced the highest rate of economic growth in recorded history, and massive improvements have been made in public health in most countries. This implies that people's basic values should be changing in those countries that have experienced rising Human Security — though not in countries that have declined or remained stagnant. This reflects our predictions for the second stage of Figure 1.

A massive body of evidence tends to confirm this expectation. Three different approaches point to this conclusion: (1) cohort analysis; (2) cross-sectional comparisons of rich and poor countries; (3) examination of actual trends observed over the past four decades. Evidence from all three perspectives suggests that major cultural changes have occurred, and that they reflect a process of intergenerational change linked with rising levels of Human Security.

[Figures 3 and 4 about here]

The data collected for the 2011-2012 wave of the World Values Survey is, at this point, only available for a limited number of countries and types of societies, but nevertheless it can be pooled and used to illustrate some of these issues. Thus Figure 3 shows that without any prior controls, the measures of security in the current wave help to predict feelings of happiness and life satisfaction, both core aspects of well-being. Thus those with the greatest personal and community insecurity report that they are also not at all happy. By contrast, those who feel secure on both of these dimensions are more likely to be very happy. Interestingly, feelings of national security and insecurity do not seem to have similar effects in the countries under comparison, suggesting that the dimensions we have distinguished do have different consequences. It remains to be seen whether these patterns hold once more countries with direct experience of conflict and war are included in the analysis. Similar relationships can be observed in the bottom part of Figure 3, with personal and community insecurity proving to be strongly related to life satisfaction.

Figure 4 examines similar descriptive patterns linking perceptions of security with trust and social tolerance (using composite measures described in the appendix). Again, without any controls, perceptions of security can be observed to be related to both these attitudes. Thus both personal and community insecurity are clearly associated with levels of social trust, while national insecurity has a strong relationship with social tolerance. 
We cannot yet present the evidence which demonstrated the direct effects of perceptions of Human Security on cultural values at macro-level across all types of society, since data for the $6^{\text {th }}$ Wave of the WVS is only currently available for a limited number of countries. Nevertheless we can analyze the effects of Materialist/Postmaterialist values which have been measured repeatedly in numerous surveys carried out since 1970, including each waves of the WVS from 1981 to 2009.

Inglehart (1977, 1990, 1997) and Norris and Inglehart (2005) have argued that the exceptional prosperity and advanced welfare states that emerged in the postwar era, together with the long peace between developed democracies that has prevailed since World War II, brought unprecedentedly high levels of economic and physical security among the publics of advanced industrial societies-- which led to intergenerational value changes among these publics. The largest relevant data base with the longest time series concerns the intergenerational shift from Materialist to Post-materialist values, where we have data from six West European countries that were surveyed at least once in most years from 1970 to the present. This data demonstrates that the younger birth cohorts, who were raised under the relatively conditions of the post-war economic miracles and welfare states, were much likelier to hold Post-materialist values than were the older birth cohorts in the same countries. Cohort analysis indicates that these age-related differences do not simply reflect life-cycle effects: as each birth cohort aged during the four decades from 1970 to 2009, the younger birth cohorts did not take on the Materialist values that their older peers held; instead, they remained as Post-materialist in 2009 as they had been in 1970. Consequently, as the younger birth cohorts gradually replaced the older ones in the adult population, the values of these six countries shifted from a $4: 1$ preponderance of Materialists over Post-materialists in 1970, to a situation in which Post-materialists were at least as numerous as Materialists in 2009. Data from countries that have had stagnant or declining economies in recent decades do not show significant differences between the values of young and old, and do not show a rising proportion of Post-materialists. Their populations' values remain overwhelmingly Materialist: the intergenerational shift toward Post-materialist values seems to occur only if a society has experienced rising levels of human security.

But intergenerational value change is not a uniquely West European phenomenon. It seems to occur whenever the formative experience of the younger birth cohorts are substantially different from those that shaped the older generations, so that the younger generation grows up under conditions that permit it to take survival for granted. In 1970, this already applied to a sizeable part of the population of Western Europe together with the U.S., Canada, Australia and a few other countries. But by 2009, many other countries, including Brazil, Russia, India and China, had been experiencing high growth rates for many years, and some of them were beginning to show substantial intergenerational value differences of the kind that were visible in Western countries in 1970. 


\section{V: Conclusions and discussion}

The four horsemen of the apocalypse, in the Book of Revelation, symbolize the catastrophic effects arising from conquest, war, famine and death. ${ }^{37}$ This Biblical vision reflects a pre-modern view of the lifethreatening risks facing the world. Considerable debate has surrounded the notion of Human Security, with proponents and critics disputing the coherence, utility and measurement of this concept. We believe that the shift from a narrow focus on military security toward the broader concept of Human Security is a natural response to the changing challenges facing developed societies, in which the cost-benefit ratio concerning inter-state war has become negative and cultural changes have made armed conflict among countries less acceptable. The extent to which humans feel secure or insecure has a major impact on their values and behavior. A revised version of modernization theory argues that high levels of development bring increasing human security that lead to changes in motivations and behavior. Economic growth generates much higher levels of per capita income, and the emergence of the welfare state makes these resources more widely and more predictably distributed.

Throughout most of history, most people have lived at the subsistence level. Survival was insecure; food was chronically scarce, making fear of foreigners realistic. In recent decades, per capita income and life expectancy have risen substantially for most of the world's population, and developed countries have been at peace with each other for the longest period in recorded history. These developments have brought a rising sense of human security to a growing share of the world's population, with far-reaching consequences. At the same time, globalization and cultural change have heightened alternative concerns, such as environmental protection and human rights. These developments reflect economic, technological and social changes linked with modernization. They have also contributed to the inter-state peace that has prevailed among democratic states for several decades. Since the end of the Cold War, security studies have broadened to take into account non-military threats, such as environmental scarcity and degradation, the spread of disease, overpopulation, refugee movements, nationalism, terrorism, and nuclear catastrophe, rather than focusing narrowly on external threats to states. In this setting, valid measures of perceptions of Human Security have become essential, both to understand the determinants of Human Security among ordinary people, and to analyze their consequences.

As long as the measurement of Human Security is limited to cross-national comparisons, however, it will fail to reflect the people-centric nature of the concept. Today, rich societies such as Norway, the United States and Japan have grown increasingly immune from life-threatening risks of extreme hunger, contagious diseases and armed violence. But a country's wealth is not a guarantee of feelings of insecurity; even the richest societies are far from safe from all natural and manmade disasters. In the global era, the effects of transnational threats such as climate change, terrorism and famine do not respect national borders. During recent decades, developing countries as diverse as Chile, China, and El Salvador have made remarkable 
progress by lifting millions of people out of poverty, expanding access to education, and extending longevity. The 2011 United Nations report on the Millennium Development Goals highlights the way that some of the poorest societies in sub-Saharan Africa, including Rwanda, Burundi, and Tanzania, have also made considerable strides towards achieving universal primary education and health care. ${ }^{38}$ Deaths and casualties from civil wars have also fallen during the last two decades. ${ }^{39}$ In the same years, however, the lives of people living in many other societies have stagnated, or worsened, according to core developmental indicators. Around the globe, it is estimated by Paul Collier that a billion people living in some least developed societies remain vulnerable to extreme poverty and life-threatening risks. ${ }^{40}$ In order to understand how feelings of vulnerability, risks and threats differ among groups and social sectors, it is essential to disaggregate the analysis to the micro-level, and to monitor subjective feelings as well as objective indices. The new battery of items contained in the $6^{\text {th }}$ wave of the World Values Survey moves towards this objective.

This opens a new research agenda, but many issues await future analysis. This study provides some preliminary findings about the role of socioeconomic inequalities in driving perceptions of insecurity but it remains to be seen how far these patterns hold when a broader range of developing countries and countries emerging from conflict are included in the comparison. This study also examined the impact of several social structural factors but we still need to establish how far perceptions of security can be explained by a range of macro-level indicators of violence and instability at national and community levels, as well as by both mediated coverage of risks (the so-called 'mean world' effect arising from exposure to television news and drama) and by the support provided by informal networks and the welfare state. Perceptions of Human Security do not necessarily correspond to objective estimates of risk. Human fears are often ill-founded; thus, the public health literature indicates that people often exaggerate the degree of threat--but they also often under-estimate risks arising from life-style choices. Nevertheless, we predict that subjective perceptions of Human Security are important drivers of human behavior, affecting psychological feelings of well-being and happiness, as well as social and political values, with important societal consequences. 
Figure 1: Heuristic Model of Human Security

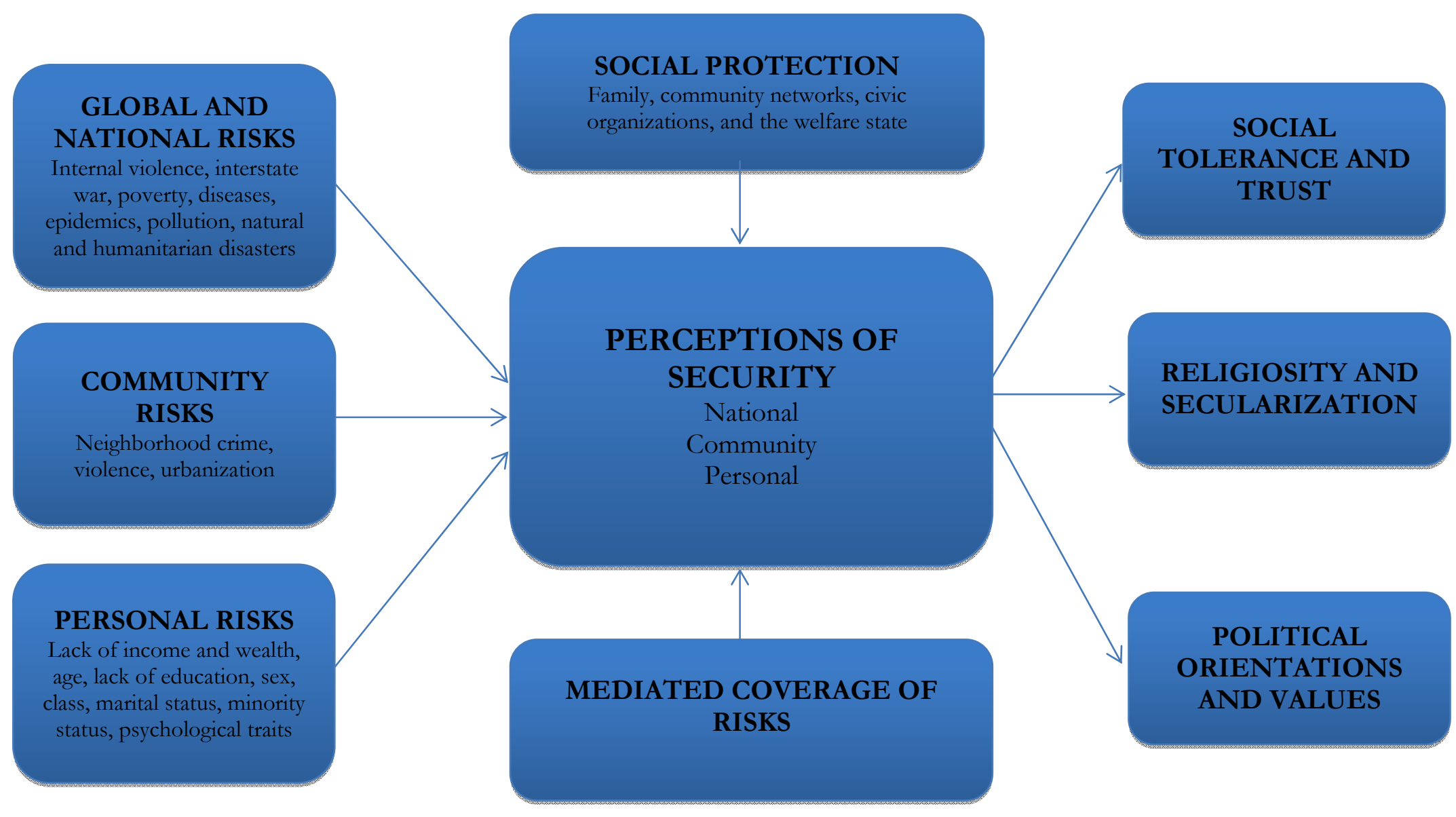




\section{Table 1: Public perceptions of security threats}

\begin{tabular}{|c|c|c|c|}
\hline & \multicolumn{3}{|c|}{ Dimensions } \\
\hline & Community & National & Personal \\
\hline \multicolumn{4}{|l|}{ COMMUNITY SECURITY: How frequently do the following things occur in your neighborhood? } \\
\hline Drug sale in streets & .788 & & \\
\hline Alcohol consumed in the streets & .783 & & \\
\hline Robberies & .775 & & \\
\hline Racist behavior & .744 & & \\
\hline Police or military interfere with people's private lives & .729 & & \\
\hline Do you live in a secure neighborhood? & .519 & & \\
\hline \multicolumn{4}{|l|}{ NATIONAL SECURITY: To what degree are you worried about the following situations? } \\
\hline A terrorist attack & & .922 & \\
\hline A war involving my country & & .920 & \\
\hline A civil war & & .890 & \\
\hline \multicolumn{4}{|l|}{ PERSONAL SECURITY: In the last 12 months, how often have you or your family...? } \\
\hline Gone without cash income. & & & .826 \\
\hline Gone without medicine or treatment & & & .818 \\
\hline Gone without enough food to eat & & & .801 \\
\hline Felt unsafe from crime in one's home. & & & .585 \\
\hline Percentage of variance & $26.1 \%$ & $19.7 \%$ & $18.9 \%$ \\
\hline
\end{tabular}

Note: Extraction Method: Principal component factor analysis with varimax rotation and kaiser normalization. See the Technical Appendix for details about all survey items.

Source: The World Values Survey 2010-11 (6 $6^{\text {th }}$ Wave): Preliminary release, September 2011 (7 countries N. 14,557). 
Table 2.Perceptions of insecurity by nation

\begin{tabular}{|c|c|c|c|}
\hline Country & National insecurity & Community insecurity & Personal insecurity \\
\hline Japan & 81 & 35 & 36 \\
\hline Morocco & 67 & 46 & 49 \\
\hline South Korea & 67 & 40 & 32 \\
\hline Spain & 64 & 40 & 32 \\
\hline Sweden & 40 & 40 & 29 \\
\hline Trinidad and Tobago & 59 & 46 & 39 \\
\hline United States & 59 & 40 & 37 \\
\hline Total & 64 & 40 & 35 \\
\hline
\end{tabular}

Note: Mean national scores on the standardized 100-point insecurity scales. See Table 1 for their components.

Source: The World Values Survey 2010-11 (6 $6^{\text {th }}$ Wave): Preliminary release, September 2011 (7 countries N. 14,557) 
Table 3: Explaining Perceptions of Insecurity

\begin{tabular}{|c|c|c|c|c|c|c|c|c|c|c|c|c|}
\hline & \multicolumn{4}{|c|}{ Personal insecurity } & \multicolumn{4}{|c|}{ Community insecurity } & \multicolumn{4}{|c|}{ National insecurity } \\
\hline & $\mathrm{b}$ & s.e. & Beta & Sig & $\mathrm{b}$ & s.e. & Beta & Sig & $\mathrm{b}$ & s.e. & Beta & Sig \\
\hline Sex & 2.025 & .327 & 2.001 & N/s & -.080 & .329 & -.003 & $\mathrm{~N} \mathrm{~N} / \mathrm{s}$ & -1.80 & 600 & -.036 & **** \\
\hline Age & -.116 & .011 & -.131 & $* * *$ & -.172 & .011 & -.209 & $* * *$ & .015 & .020 & .010 & $\mathrm{~N} / \mathrm{s}$ \\
\hline Household income & -.663 & .099 & -.091 & $* * *$ & -.014 & .099 & -.002 & $\mathrm{~N} / \mathrm{s}$ & -.265 & .181 & -.022 & $\mathrm{~N} / \mathrm{s}$ \\
\hline $\begin{array}{l}\text { Wealth (family savings } \\
\text { during past year) }\end{array}$ & -3.34 & .191 & -.202 & $* * *$ & -1.15 & .192 & -.075 & $* * *$ & -2.36 & .351 & -.087 & $* * *$ \\
\hline Education & -1.09 & .071 & -.180 & $* * *$ & -.588 & .071 & -.104 & $* * *$ & -.997 & .130 & -.100 & $* * *$ \\
\hline Subjective social class & -2.58 & .235 & -.154 & $* * *$ & -1.45 & .236 & -.093 & $* * *$ & -.431 & .431 & -.016 & $\mathrm{~N} / \mathrm{s}$ \\
\hline Marital status & -.202 & .358 & -.006 & $\mathrm{~N} / \mathrm{s}$ & -1.24 & .360 & -.042 & $* * *$ & 3.19 & .656 & .061 & $* * *$ \\
\hline Chief wage-earner employed & -1.22 & .470 & -.036 & $* * *$ & -2.60 & .472 & -.083 & $* * *$ & 1.85 & .861 & .033 & $*$ \\
\hline Respondent employed & 1.14 & .411 & .037 & $* * *$ & 1.00 & .413 & .035 & $* *$ & -1.29 & .754 & -.025 & $\mathrm{~N} / \mathrm{s}$ \\
\hline $\begin{array}{l}\text { Second generation } \\
\text { immigrant }\end{array}$ & 1.59 & .616 & .028 & $* *$ & 3.39 & .619 & .063 & $* * *$ & -5.95 & 1.129 & -.063 & $* * *$ \\
\hline Constant & 36.8 & & & & 47.4 & & & & 62.6 & & & \\
\hline Adjusted R2 & .218 & & & & .094 & & & & .035 & & & \\
\hline
\end{tabular}

Note: OLS regression models where the Personal Security standardized 100-point scale is the dependent variable. All models were checked with tolerance statistics to be free of multicollinearity. The columns represent the unstandardized beta coefficients (b), the Standard Error (s.e.), the Standardized Beta (B) and the statistical significance of the coefficients $(\mathrm{P}) . *=>.05 * *=>.01 * * *=>.001$.

Source: The World Values Survey 2010-11 (6 $6^{\text {th }}$ Wave): Preliminary release, September 2011 (7 countries N. 14,557). 
Figure 2: Perceptions of personal insecurity by household income and nation

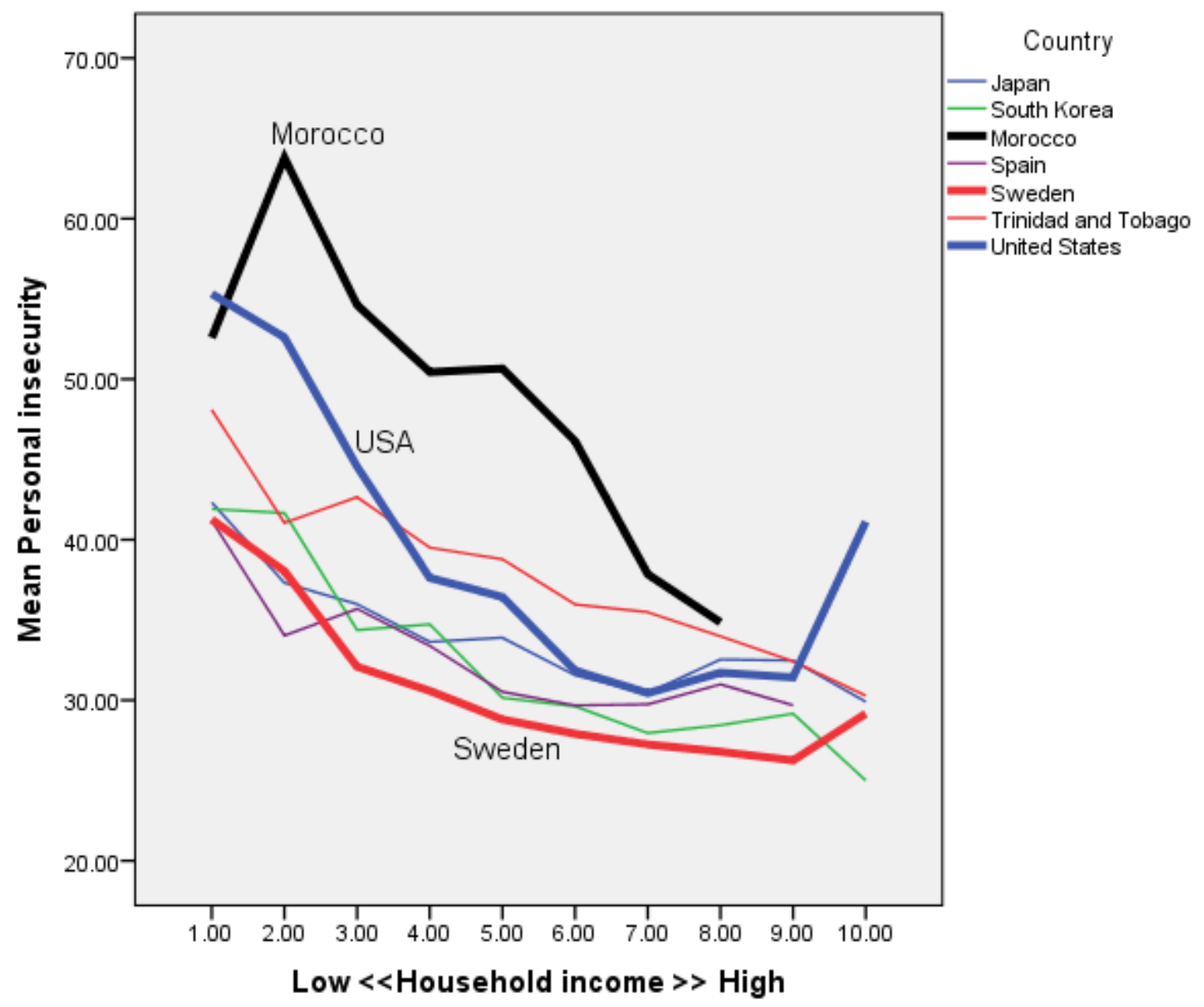

Source: The World Values Survey 2010-11 (6 $6^{\text {th }}$ Wave): Preliminary release, September 2011 (7 countries N. 14,557) 
Figure 3: Insecurity matters for well-being

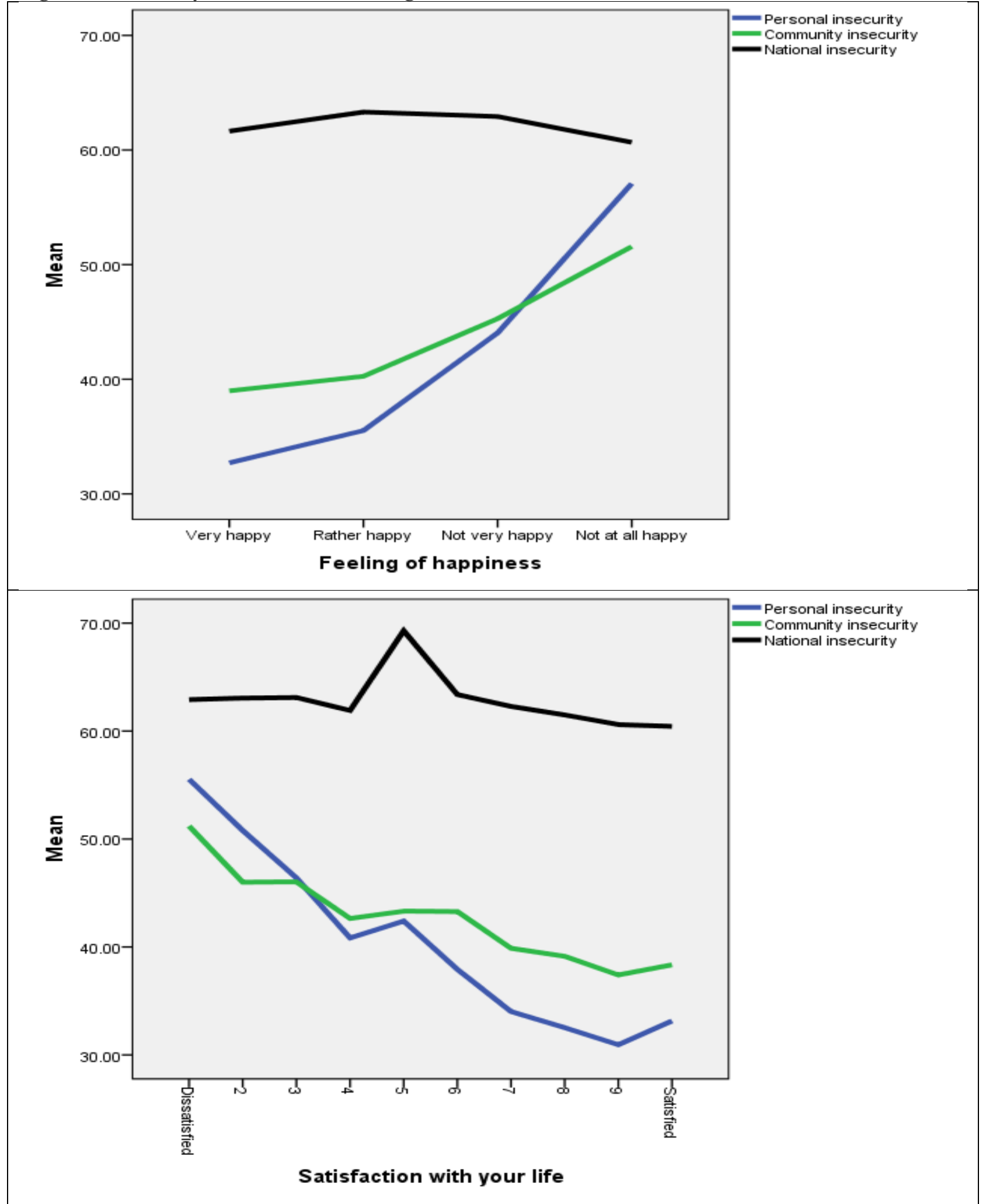

Source: The World Values Survey 2010-11 (6 $6^{\text {th }}$ Wave): Preliminary release, September 2011 (7 countries N. 14,557) 
Figure 4: Insecurity matters for trust and tolerance

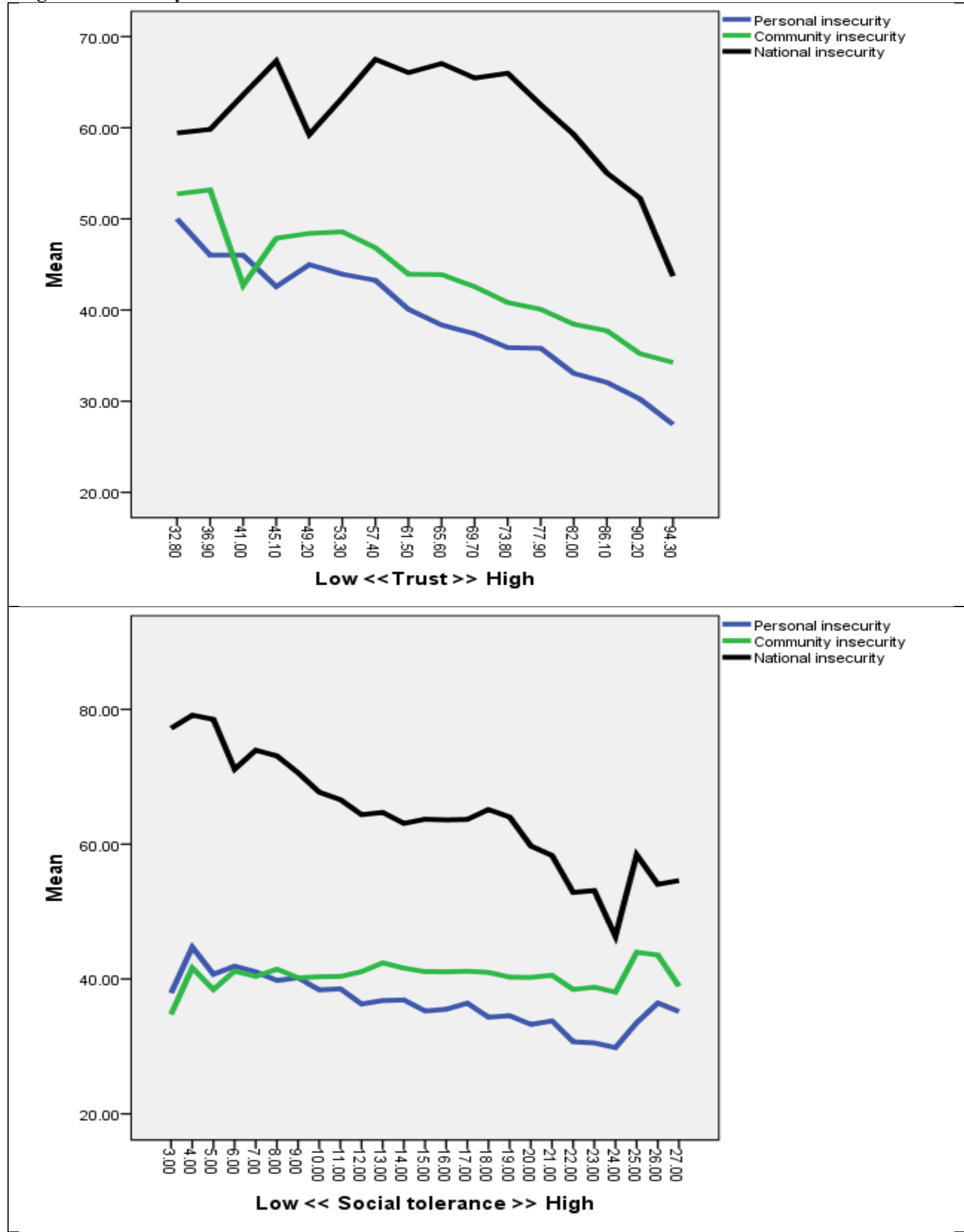

Source: The World Values Survey 2010-11 (6 $6^{\text {th }}$ Wave): Preliminary release, September 2011 (7 countries N. 14,557) 
Technical Appendix A

\begin{tabular}{|c|c|c|c|c|c|}
\hline In the last 12 month, how often have you or your family & Often & Sometimes & Rarely & Never & $\mathrm{DK} / \mathrm{NA}$ \\
\hline V188. Gone without enough food to eat & 1 & 2 & 3 & 4 & -1 \\
\hline V189. Felt unsafe from crime in your home & 1 & 2 & 3 & 4 & -1 \\
\hline $\begin{array}{l}\text { V190. Gone without medicine or medical treatment that } \\
\text { you needed }\end{array}$ & 1 & 2 & 3 & 4 & -1 \\
\hline V191. Gone without a cash income & 1 & 2 & 3 & 4 & -1 \\
\hline
\end{tabular}

2. Community security index

\begin{tabular}{|c|c|c|c|c|c|}
\hline How frequently do the following things occur in your neighborhood? & $\begin{array}{c}\text { Very } \\
\text { frequently }\end{array}$ & $\begin{array}{c}\text { Quite } \\
\text { frequently }\end{array}$ & $\begin{array}{c}\text { Not } \\
\text { frequently }\end{array}$ & $\begin{array}{l}\text { Not at all } \\
\text { frequently }\end{array}$ & $\begin{array}{l}\mathrm{DK} / \\
\mathrm{NA}\end{array}$ \\
\hline V171. Robberies & 1 & 2 & 3 & 4 & -1 \\
\hline V172. Alcohol consumption in the streets & 1 & 2 & 3 & 4 & -1 \\
\hline V173. Police or military interfere with people's private life & 1 & 2 & 3 & 4 & -1 \\
\hline V174. Racist behavior & 1 & 2 & 3 & 4 & -1 \\
\hline V175. Drug sale in streets & 1 & 2 & 3 & 4 & -1 \\
\hline
\end{tabular}

V170. Could you tell me how secure do you feel these days in your neighborhood?

\begin{tabular}{|l|c|}
\hline Very secure & 1 \\
\hline Quite secure & 2 \\
\hline Not very secure & 3 \\
\hline Not at all secure & 4 \\
\hline DK/NA & -1 \\
\hline
\end{tabular}

3. National security index

\begin{tabular}{|c|c|c|c|c|c|}
\hline To what degree are you worried about the following situations? & $\begin{array}{l}\text { Very } \\
\text { much }\end{array}$ & $\begin{array}{c}\text { A good } \\
\text { deal }\end{array}$ & $\begin{array}{l}\text { Not } \\
\text { much }\end{array}$ & Not at all & $\begin{array}{l}\mathrm{DK} / \\
\mathrm{NA}\end{array}$ \\
\hline V183. A war involving my country & 1 & 2 & 3 & 4 & -1 \\
\hline V184. A terrorist attack & 1 & 2 & 3 & 4 & -1 \\
\hline V185. A civil war & 1 & 2 & 3 & 4 & -1 \\
\hline
\end{tabular}

\section{Social tolerance scale}

- Do men make better political leaders than women?

- When jobs are scarce, do men have more right to a job than women?

- Is a university education more important for a boy than for a girl?

- When jobs are scarce, should employers give preference to people of (your nationality) over foreigners?

- Would you be willing to have a foreign worker/immigrant as a neighbor?

- Would you be willing to have someone of another religion as a neighbor? 
- Would you be willing to have a homosexual as a neighbor?

- Is homosexuality ever acceptable?

\section{Social trust scale}

Composite scale of how much the respondent trusts their family, their neighborhood, people you know personally, people you meet for the first time, people of another religion, people of another nationality.

$\begin{array}{ll}\text { 6. Structural variables } & \text { Coding } \\ \text { Sex } & \text { Male=1, female }=0 \\ \text { Age } & \text { In years }(18-95) \\ \text { Household income } & \text { Categorized scale from low income }(1) \text { to high }(10) \\ \text { Family savings during past year } & \text { From spent savings and borrowed money }(1) \text { to save money (4) } \\ \text { Education } & \text { Highest qualification: No qualification }(1) \text { to university degree }(9) \\ \text { Subjective social class } & \text { From lower class }(1) \text { to upper class }(5) \\ \text { Marital status } & \text { Married or living as married }=1 \text {, or other status }=0 . \\ \text { Chief wage-earner employed } & \text { Paid work full-time or part-time }=1 \text {, or other work status }=0 \\ \text { Respondent employed } & \text { Paid work full-time or part-time }=1 \text {, or other work status }=0 \\ \text { Second generation immigrant } & \text { Mother or father immigrant }=1 \text {, or else }=0 .\end{array}$


INGLEHART AND NORRIS: SKYTTE LECTURE 10/13/2011 10:10 AM

Acknowledgments: We would like to express our deep appreciation to the Johan Skytte Foundation and the award committee, especially Li Bennich-Bjorkman. The paper was first presented at the Johan Skytte Lecture at the University of Uppsala on 23 $3^{\text {rd }}$ September 2011. We are also most grateful to the Swedish International Development Agency (Sida) for supporting the World Values survey fieldwork in several low-income countries, the Riksbankens Jubileumsfond for supporting fieldwork in Sweden, the National Science Foundation for supporting the survey in the U.S. and several other countries, and the Russian Ministry of Education and Science and the Higher School of Economics, St Petersburg and Moscow for supporting the surveys in Russia and several ex-Soviet countries.

${ }^{1}$ See Taylor Owen. 2004. 'Human Security - Conflict, critique and consensus: Colloquium remarks and a proposal for a threshold-based definition.' Security Dialogue 35(3): 373-87; Sandra J. MacLean, David R. Black \& Timothy M. Shaw, eds, 2006. A Decade of Human Security: Global Governance and New Multilateralisms. Aldershot \& Burlington, VT: Ashgate; Shahrbanou Tadjbakhsh and Anuradha M. Chenoy. 2007. Human Security: Concepts and implications. New York: Routledge; Ken Booth. 2007.Theory of World Security. New York: Cambridge: Cambridge University Press; Mary Kaldor. 2007. Human Security. Polity Press; Barry Buzan and Lena Hansen. 2009. The Evolution Of International Security Studies. New York: Cambridge University Press; Derek S. Reveron and Kathleen A. Mahoney-Norris. 2011. Human Security in a Borderless World. Westview Press.

2 Shahrbanou Tadjbakhsh and Anuradha M. Chenoy. 2007. Human Security: Concepts and Implications London \& New York: Routledge. Ch 3; Nicholas Thomas and William T. Tow. 2002. 'The utility of Human Security: Sovereignty and humanitarian intervention.' Security Dialogue 33(2): 177-92; E.Burger. 2004.'Human Security and the Crisis of Public Health Care in Malawi.' Canadian Journal of Development Studies 25 (2): 239-55.

${ }^{3}$ Roland Paris. 2001. 'Human Security: Paradigm shift or hot air?' International Security 26(2):87-102; Y.F. Khong. 2001. 'Human Security: a shotgun approach to alleviating human misery?' Global Governance 7(3): 231-36; Barry Buzan. 2004. 'A reductionist, idealistic notion that adds little analytic value', Security Dialogue, 35(3): 369-70.

${ }^{4}$ D. Bosold and W. von Bredow. 2006. 'Human Security: A radical or rhetorical shift in Canada's foreign policy?' International Journal 61(4): 829-44.

${ }^{5}$ W. Nelles. 2002. 'Canada's human security agenda in Kosovo and Beyond: Military intervention versus conflict prevention.' International Journal 57(32): 459-79; Robert Muggah, and Keith Krause, 2006. 'A true measure of success? The discourse and practice of human security in Haiti.' In A Decade of Human Security: Global Governance and New Multilateralisms. Edited by Sandra J. MacLean, David R. Black, and Timothy M. Shaw. Aldershot \& Burlington, VT: Ashgate. pp.113-126; E. Riddell-Dixon. 2005. ‘Canada's Human Security Agenda - Walking the Talk?’ International Journal 60(4): 1067-92; T. Hsien-Li. 2006. 'Not just global rhetoric: Japan's substantive actualization of its human security foreign policy.' International Relations of the Asia-Pacific 10 (1): 159-87.

${ }^{6}$ See, David A. Hastings. 2011. 'The Human Security Index: An update and a new release.' http://www.HumanSecurityIndex.org ; Sascha Werthes, Corinne Heaven and Sven Vollnhals. 2011. Assessing Human Security Worldwide: The Way To A Human (In)Security Index. University of Essen: Institut fur Entwickland und Frieden (INEF) Report 102. 
${ }^{7}$ David A. Hastings. 2011. 'The Human Security Index: An update and a new release.'

http://www.HumanSecurityIndex.org; Sascha Werthes, Corinne Heaven and Sven Vollnhals. 2011. Assessing Human Security Worldwide: The Way To A Human (In)Security Index. University of Essen: Institut fur Entwickland und Frieden (INEF) Report 102.

${ }^{8}$ Ronald Inglehart. 1997. Modernization and Postmodernization: Cultural, Economic and Political Change in 43 Societies. Princeton: Princeton University Press; Pippa Norris and Ronald Inglehart. 2011. Sacred and Secular. New York: Cambridge University Press 2nd Edition; Ronald Inglehart and Christian Welzel. 2005. Modernization, Cultural Change, and Democracy: The Human Development Sequence. New York: Cambridge University Press.

${ }^{9}$ S. Neil MacFarlane and Yuen Foong Khong. 2006. Human Security and the UN: A Critical History. Indiana University Press.

${ }^{10}$ United National Development Programme. 1994. Human Development Report p. 22. New York: UNDP.

${ }^{11}$ United Nations Development Programme. 1994. Human Development Report. New York: UNDP.

http://hdr.undp.org/en/humandev/

${ }^{12}$ Franklin D. Roosevelt. January 6, 1941. State of the Union.

${ }^{13}$ C. Thomas, C. 2001. 'Global Governance, Development and Human Security: Exploring the Links.' Third World Quarterly 22(2): 159-75.

${ }^{14}$ J. Brunnee and S. J. Toope. 2004. 'Canada and the use of force: Reclaiming Human Security.' International Journal 59(2): 247-60; D. Bosold and W. von Bredow. 2006. 'Human Security: A Radical or rhetorical shift in Canada's foreign policy?' International Journal 61(4): 829-44.

15 T. Hsien-Li. 2005. 'Not just global rhetoric: Japan's substantive actualization of its human security foreign policy.' International Relations of the Asia-Pacific 10 (1): 159-87.

${ }^{16}$ Commission on Human Security, 2003. Human security Now. New York: CHS.

${ }^{17}$ Juliet Pietsch and Ian McAllister. 2010. 'Human security in Australia: public interest and political consequences.' Australian Journal of International Affairs, 64 (2): 225-244.

${ }^{18}$ Mary Kaldor, Mary Martin, and Sabine Selchow. 2007. 'Human security: a new strategic narrative for Europe.' International Affairs 83(2): 273-+; Mary Martin and Mary Kaldor. Eds. 2011. The European Union and European Security. Routledge.

${ }^{19}$ Robert Muggah, and Keith Krause, 2006. 'A true measure of success? The discourse and practice of human security in Haiti.' In A Decade of Human Security: Global Governance and New Multilateralisms. Edited by Sandra J. MacLean, David R. Black, and Timothy M. Shaw. Aldershot \& Burlington, VT: Ashgate. pp.113-126; E. Riddell-Dixon. 2005. 'Canada's Human Security Agenda - Walking the Talk?' International Journal 60(4): 1067-92.

${ }^{20}$ Timothy M. Shaw, Sandra J. MacLean and David R. Black, 2006. Introduction: A decade of human security: what prospects for global governance and new multilateralisms? In A Decade of Human Security: Global Governance and New 
Multilateralisms. Edited by Sandra J. MacLean, David R. Black, and Timothy M. Shaw. Aldershot \& Burlington, VT: Ashgate. pp.8-9.

21 The expansion in peacekeeping activities and the settlement of civil wars has attracted a substantial literature. See, for example, Roland Paris, 2004. At War's End: Building Peace after Civil Conflict. Cambridge: Cambridge University Press; HoWon Jeong. 2005. Peace-building in Post-conflict Societies. Boulder, Co: Lynne Rienner; Paul Collier and Nicholas Sambanis. Eds. 2005. Understanding Civil War. Washington DC: The World Bank; James Dobbins et al. 2005. The UN's Role in Nation-building: From the Congo to Iraq. Santa Monica: Rand Corporation; Michael W.Doyle and Nicholas Sambanis. 2006. Making War and Building Peace. Princeton: Princeton University Press; Anna K. Jarsad and Timothy D. Sisk. Eds. 2008. From War to Democracy. New York: Cambridge University Press; Lise Morjé Howard. 2009. UN peacekeeping in civil wars. New York: Cambridge University Press; Monica Toft. 2010. Securing the Peace: The Durable Settlement of Civil Wars. Princeton: Princeton University Press.

22 Roland Paris and Timothy D. Sisk. Eds. 2009. The Dilemmas of State-building. New York: Routledge.

${ }^{23}$ Marlies Glasius. 2008. 'Human security from paradigm shift to operationalization: job description for a human security worker.' Security Dialogue 39(1): 31-54.

${ }^{24}$ Roland Paris. 2001. 'Human Security: Paradigm Shift or Hot Air?’ International Security 26(2):87-102; Barry Buzan. 2004. 'A reductionist, idealistic notion that adds little analytic value', Security Dialogue, 35(3): 369-70.

${ }^{25}$ Yuen Foong Khong. 2001. 'Human Security: A shotgun approach to alleviating human misery?’ Global Governance 7 (3): 231-36.

${ }^{26}$ Marlies Glasius. 2008. 'Human security from paradigm shift to operationalization: job description for a human security worker.' Security Dialogue 39(1): 31-54.

${ }^{27}$ Gary King and Christopher J. L. Murray. 2001. 'Rethinking Human Security.' Political Science Quarterly 116 (4): 585-610.

${ }^{28}$ Gary King and Christopher J. L. Murray. 2001. 'Rethinking Human Security.' Political Science Quarterly 116 (4): 585-610.

${ }^{29}$ Roland Paris. 2001. ‘Human Security: Paradigm Shift or Hot Air?’ International Security 26(2):87-102.

${ }^{30}$ David A. Hastings. 2011. 'The Human Security Index: An update and a new release.' http://www.HumanSecurityIndex.org; Sascha Werthes, Corinne Heaven and Sven Vollnhals. 2011. Assessing Human Security Worldwide: The Way To A Human (In)Security Index. University of Essen: Institut fur Entwickland und Frieden (INEF) Report 102. http://inef.uni-due.de

31 Roland Paris. 2001. ‘Human Security: Paradigm Shift or Hot Air?’ International Security 26(2):87-102.

${ }^{32}$ United Nations. 2011. The Millennium Development Goals Report 2011. New York: UN.

${ }^{33}$ See the Uppsala Conflict Data Program www.ucdp.uu.se.

34 An exception which attempts to measure and compare Human Security at an individual level, although based on an unrepresentative sample, can be found in Caitlin O. Mahoney and Tatiana M. Pinedo. 2007. 'Human security in 
communities in Costa Rica and the United States.' Journal of Social Issues 63(2): 353-68. Another attempt to monitor attitudes towards human security in Australia was developed by Juliet Pietsch and Ian McAllister. 2010. 'Human security in Australia: public interest and political consequences.' Australian Journal of International Affairs, 64 (2): 225-244.

35 T. Chiricos, S. Eschholz, and M. Gertz. 1997. 'Crime, news and fear of crime: Toward an identification of audience effects.' Social Problems 44(3): 342-357; Lisa A. Kort-Butler and Kelley Hartshorn. 2011. 'Watching the detectives: Crime programming, fear of crime, and attitudes about the criminal justice system. ' Sociological Quarterly 52(1): 36-55

36 Ronald Inglehart and Pippa Norris. 2003. Rising Tide. New York: Cambridge University Press.

37 The Four Horsemen of the Apocalypse are described in the last book of the New Testament of the Bible, called the Book of Revelation.

38 United Nations. 2011. The Millennium Development Goals Report 2011. New York: UN.

39 Ted Robert Gurr, Joseph Hewitt, Jonathan Wilkenfeld. 2011. Peace and Conflict 2010. Maryland: CIDCM/University of Maryland/Paradigm Publishers.

40 Paul Collier 2008. The Bottom Billion. New York: Oxford University Press. 